Review

\title{
Vpu Protein: The Viroporin Encoded by HIV-1
}

\section{María Eugenia González}

Unidad de Expresión Viral, Centro Nacional de Microbiología, Instituto de Salud Carlos III, Carretera de Majadahonda-Pozuelo Km 2, Majadahonda, Madrid 28220, Spain; E-Mail: megonzalez@isciii.es; Tel.: +34-91-822-3698; Fax: +34-91-509-7966

Academic Editor: José Luis Nieva

Received: 29 June 2015 / Accepted: 28 July 2015 / Published: 4 August 2015

\begin{abstract}
Viral protein $\mathrm{U}(\mathrm{Vpu})$ is a lentiviral viroporin encoded by human immunodeficiency virus type 1 (HIV-1) and some simian immunodeficiency virus (SIV) strains. This small protein of 81 amino acids contains a single transmembrane domain that allows for supramolecular organization via homoligomerization or interaction with other proteins. The topology and trafficking of $\mathrm{Vpu}$ through subcellular compartments result in pleiotropic effects in host cells. Notwithstanding the high variability of its amino acid sequence, the functionality of $\mathrm{Vpu}$ is well conserved in pandemic virus isolates. This review outlines our current knowledge on the interactions of Vpu with the host cell. The regulation of cellular physiology by $\mathrm{Vpu}$ and the validity of this viroporin as a therapeutic target are also discussed.
\end{abstract}

Keywords: Vpu; HIV-1; Viroporin; protein trafficking; membrane permeability; ion transport; membrane pore; antiretroviral target

\section{Introduction}

The human immunodeficiency virus type 1 (HIV-1) Viral protein $\mathrm{U}(\mathrm{Vpu})$ protein is an 81-amino acid type I transmembrane protein [1,2]. Its characteristic sequence elements together with its functioning during the virus life cycle are typical for proteins belonging to the viroporin family $[3,4]$. Specifically, the presence of a single transmembrane domain, a luminal amino terminus, and a cytosolic carboxy terminus in the protein architecture classifies Vpu as a member of class IA viroporins [5]. The Vpu protein is translated from a Rev-regulated bicistronic mRNA that also encodes the env gene. Thus, during the virus replication cycle, $\mathrm{Vpu}$ and envelope precursor protein (Env) proteins are produced late and in a coordinated manner [6]. The translated Vpu protein modifies the distribution and/or concentration of membrane proteins in host cells. This interaction with the host cell may account for two of the main 
functions of Vpu: the downregulation of the CD4 receptor from the cell surface and the enhancement of the release of progeny virions from infected cells $[7,8]$. This review provides an updated overview about the interaction of Vpu protein with host cell membranes and its consequences for the functional integrity of subcellular compartments. How these interactions may impact on virus spread from the host cells and also the potential of Vpu viroporin as an antiviral target are discussed.

\section{The Role of Vpu Protein in the Spread of HIV-1 from Infected Cells}

Functional analysis of full-length and truncated forms of HIV-1 Vpu pointed to a direct correlation between structure, topology, and function for this membrane protein [9]. Early studies mapped the two biological activities of Vpu protein in two separable structural domains: the transmembrane $\mathrm{N}$-terminus and the cytoplasmic C-terminus [10]. Further studies showed that conserved motifs in both regions preserve the topology and supramolecular organization required for both activities (Figure 1).

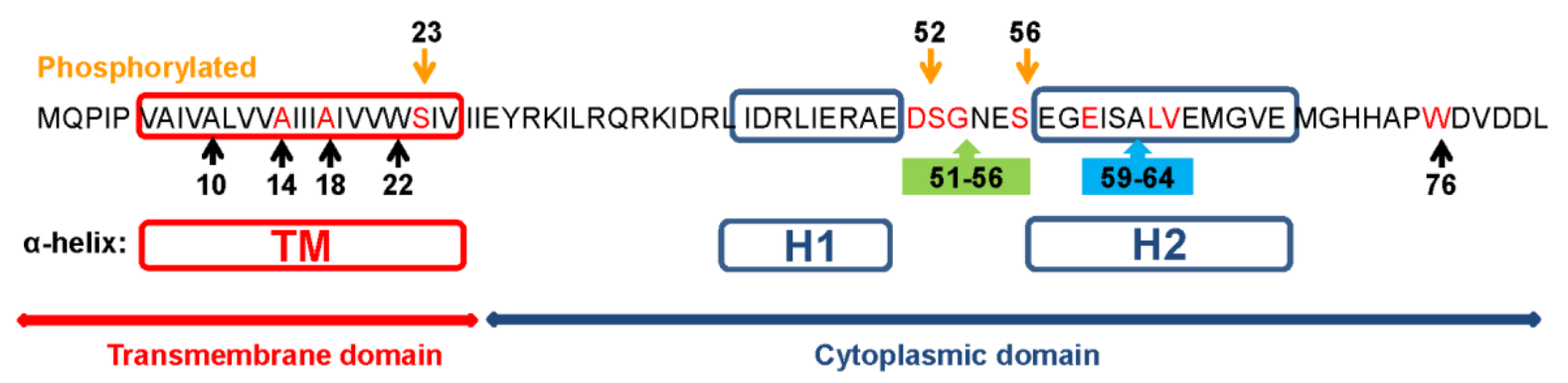

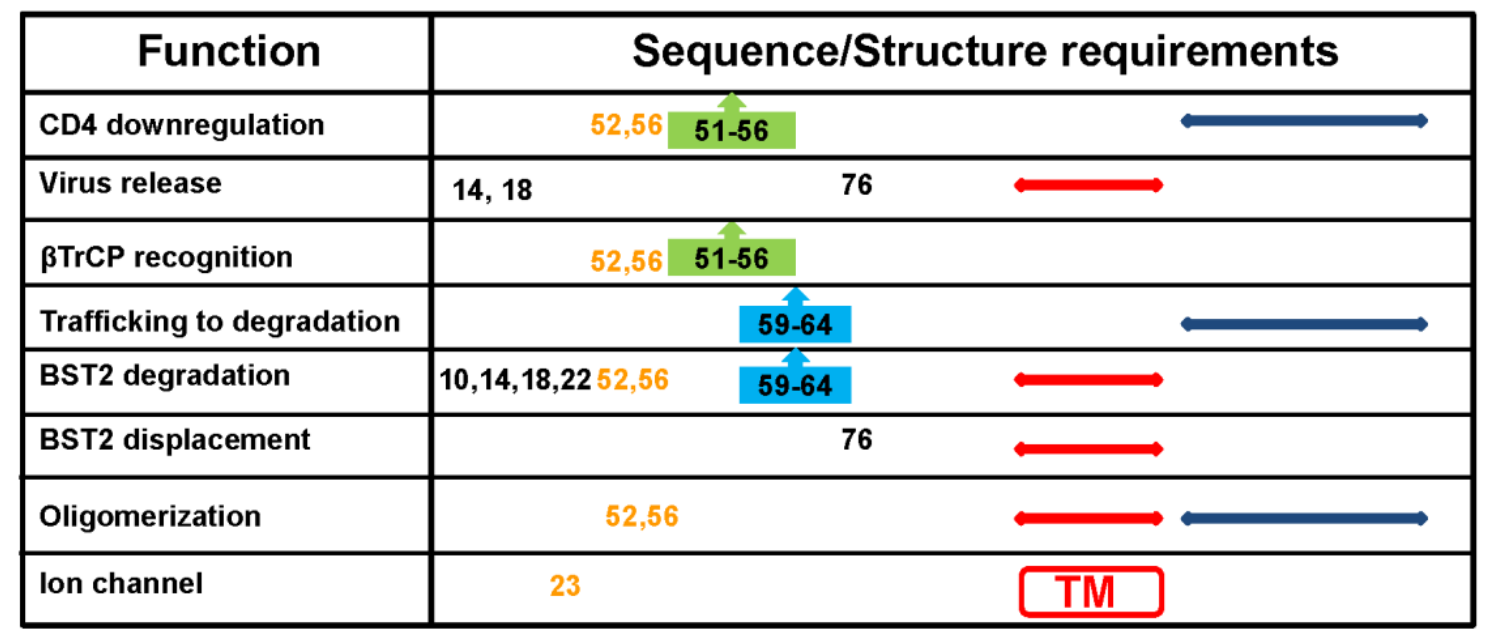

Figure 1. Sequence and structure requirements for Viral protein $U(\mathrm{Vpu})$ functionality. Vpu from the HXB2 strain is the reference amino acid sequence showing conserved amino acid (red), motifs (boxes), structural domains, and predicted helices. Numbers refer to amino acid positions. Table summarizes the consensus published data of each function. Each function was separately characterized, using different approaches. Further coordinated studies are needed to compare requirements of these functions. 


\subsection{Downregulation of CD4}

HIV-1 Negative Regulatory Factor (Nef) and Vpu proteins downmodulate the CD4 receptor in infected cells. While Nef degrades pre-existing CD4 at the plasma membrane, Vpu targets the newly synthesized CD4 molecules in the endoplasmic reticulum (ER) [7]. It is well established that this modulation is independent of Env expression [11,12]. The cytoplasmic domain of the Vpu protein regulates this activity. This hydrophilic region consists of two amphipathic alpha-helices joined by a hinge region formed by the conserved DSGNES motif which can be phosphorylated by casein kinase II [13]. The phosphorylation of serines S52 and S56 is essential for this activity [14,15]. The proposed model for Vpu-induced downmodulation of cell surface CD4 is discussed below. Of note, the viral-induced downmodulation of CD4 contributes to diminish CD4-Env complexes carrying Env epitopes targeted by antibodies that mediate the antibody-dependent cell-mediated cytotoxicity (ADCC) at the cell surface $[16,17]$. This protection from ADCC prevents the elimination of infected cells and consequently contributes to virus propagation.

\subsection{Enhancement of Virus Release}

Vpu-induced enhancement of the release of viral particles from infected cells was first mapped to the transmembrane region of $\mathrm{Vpu}$ [10]. Feasible pathways explaining the promotion of virus release by $\mathrm{Vpu}$ are still debated. On one hand, early studies showed cell-type dependence for the promotion of productive infections by $\mathrm{Vpu}$ [18-20]. Accordingly, it was suggested that $\mathrm{Vpu}$ does not interact directly with viral proteins, but rather mediates this function via cellular factors. On the other hand, some other studies focused on the ion channel activity of Vpu. Thus, it was suggested that the Vpu-induced movement of monovalent cations across the internal cellular membranes creates cellular conditions, including the reorganization of raft structures, that promote budding from the plasma membrane of infected cells $[21,22]$.

\subsubsection{Vpu Antagonizes BST2}

The model based on antiviral host restriction has been largely developed through the identification of the interferon (IFN)- $\alpha$-induced glycoprotein Bone Marrow Stromal Cell Antigen 2 (BST2) (tetherin/CD317), which inhibits the release of virus and is antagonized by Vpu [23,24]. BST2 is a type II transmembrane protein with two membrane anchors, a transmembrane domain near the $\mathrm{N}$-terminus and a glycophosphatidylinositol (GPI)-linked anchor at the $\mathrm{C}$ terminus; both anchors are joined by an ectodomain [25]. It is thought that BST2 directly tethers viral particles to the cellular membrane [26]. $\mathrm{Vpu}$ removes this host restriction factor from the plasma membrane of infected cells and therefore excludes it from assembling virions [27]. The interactions between the transmembrane domains of Vpu and BST2 are proposed to be necessary for this process, leading to the degradation of BST2 in lysosomes or the proteasome [28,29]. Further, the primary sequence of the Vpu transmembrane domain governs the species-specific exclusion of BST2 [30].

Additionally, the cytoplasmic domain of $\mathrm{Vpu}$ is involved in the subcellular redistribution of BST2, displacing it just out of viral assembly sites at the plasma membrane [31,32]. BST2 resides in lipid rafts at the cell surface and membranes of the trans-Golgi network (TGN) [25]. Interactions between BST2 and $\mathrm{Vpu}$ at these cellular compartments are discussed below. 


\subsubsection{Vpu Induces Changes in Ionic Currents of Cellular Membranes}

The ion channel model was first proposed from the observation that Vpu may form homo-oligomers via the conserved hydrophobic membrane spanning helix at the transmembrane domain [33]. Moreover, structural similarities between Vpu and a second viroporin, influenza virus M2, bolstered the search for ion channel activity of this lentiviral protein in lipid bilayers [3,21,34]. Thus, computational simulation studies with the Vpu transmembrane peptide suggested that the most likely channel assembly is a pentamer [35]. Further studies in Xenopus oocytes revealed that Vpu forms channels that are weakly selective for monovalent cations over anions [36]. In this cellular model, mutated Vpu showed a correlation between $\mathrm{K}+$ conductance alteration and CD4 degradation [37]. Nuclear magnetic resonance (NMR) spectroscopy studies revealed that the C-terminal helices modulate or promote the oligomerization of $\mathrm{Vpu}$ in the membrane and stabilize the conductive state of the channel [38]. Additional studies using permissive and restrictive human cells correlated Vpu-induced enhancement of viral release with membrane potential depolarization by Vpu [39]. Consequently, it is possible that the size of background $\mathrm{K}+$ conductance could determine whether a particular cell type is permissive or restrictive for the infection by Vpu-defective virus. Curiously, an interaction between Vpu and the cellular weak inward K+ rectifier TASK1 was observed in cultured cells and AIDS lymphoid tissues [40]. The suppression of TASK1 conductance together with the reduction of Vpu-induced virus release from cells correlates with degradation of TASK1. Evidence that Vpu may disturb K+ transport was found also in Saccharomyces cerevisiae [41]. Inducible expression of Vpu impaired the growth of wild type yeast but, conversely, rescued the growth phenotype of defective $\mathrm{K}+$-uptake mutants. These Vpu-promoted effects on yeast were dependent on high extracellular $\mathrm{K}+$ concentration, thus, concurring with the membrane depolarization of infected cells during Vpu-enhanced virus release.

Both of the main functions of $\mathrm{Vpu}$, downmodulation of CD4 and enhancement of virus release, contribute to the cell-to-cell and cell-free spread of virus [42,43]. The variable supramolecular organization and/or the turnover of Vpu may modulate distinct interactions of the viroporin with cellular membranes $[44,45]$.

\section{Modification of Protein Trafficking and Membrane Integrity}

Vpu is non-packed into virions though co-localizes with Env within the TGN where the viroporin primarily resides. Other localizations where $\mathrm{Vpu}$ has been found are the endosomal system, plasma membrane (PM), and the ER. Notably, Vpu does not oligomerize in the ER, but does so in the Golgi region or in post-Golgi vesicles [46]. Thus, it is possible that different functions for monomeric and oligomeric forms of Vpu exist, which are dependent on the membrane compartment (Figure 2).

Together with the Nef protein, Vpu modifies the subcellular distribution of membrane proteins, endowing infected cells with optimal assembly and budding at membrane microdomains [47].

The downregulation of several membrane proteins by $\mathrm{Vpu}$, including cell surface receptors, viral glycoproteins, and antiviral factors, has been reported [48] (Table 1). Among them, CD4 and BST2 stand out because of their special biological significance for virus transmission. 


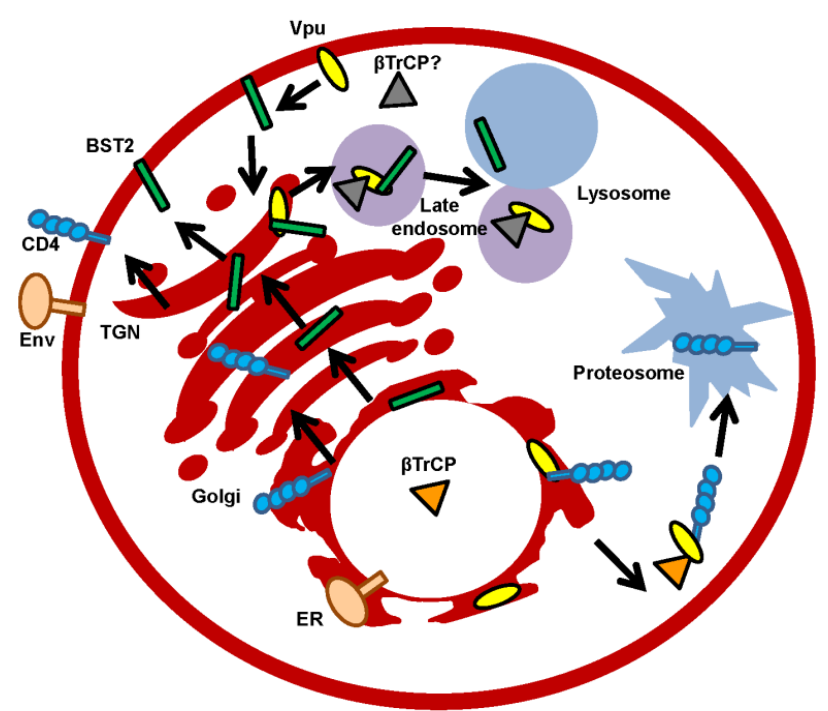

Figure 2. Subcellular localizations of Vpu protein. Vpu modifies the protein transport of newly synthesized proteins. Degradation through the lysosome pathway (illustrated with Bone Marrow Stromal Cell Antigen 2 (BST2)) or the proteasome pathway (illustrated with $\mathrm{CD} 4)$ are included. $\beta$-transducing-repeat-containing protein $(\beta \mathrm{TrCP})$ or unknown cellular cofactor and also the two possible locations (trans-Golgi network (TGN) and plasma membrane (PM)) where BST2 and Vpu converge and traffic are depicted.

Table 1. Proteins modulated by Vpu. Cellular and viral proteins respond to the presence of intracellular Vpu by altering their trafficking or intracellular concentration. The table includes membrane proteins exposed to the cell surface (blue), proteins involved in protein trafficking or virus release (purple), $\mathrm{K}+$ channel (pink) and virus-encoded proteins (green).

\begin{tabular}{ccc}
\hline Protein & Modification & References \\
\hline BST2/tetherin/CD317 & downregulation/localization & {$[24]$} \\
CCR7 & downregulation & {$[49]$} \\
CD1d & downregulation & {$[50,51]$} \\
CD4 & downregulation & {$[11]$} \\
CD40 & upregulation & {$[52]$} \\
CD81 & downregulation & {$[53]$} \\
CD155/PVR & downregulation & {$[54,55]$} \\
CDL62 & localization & {$[56]$} \\
MHC-I & downregulation & {$[57]$} \\
NTB-A & localization? & {$[58,59]$} \\
AP-1 & localization & {$[60]$} \\
BTrCP & localization & {$[61]$} \\
TASK-1 & downregulation & {$[62]$} \\
Env (HIV-1) & downregulation & {$[40]$} \\
Gag (HIV-1) & localization & {$[7,63]$} \\
Glycoprotein (SV) & localization & {$[63,64]$} \\
TSPANs $(25,26,28$ and 30) & processing/downregulation & {$[65]$} \\
\hline
\end{tabular}


It is now well established that $\mathrm{Vpu}$ targets CD4 and BST2 proteins for degradation in a $\beta$-transducing-repeat-containing protein $(\beta \operatorname{TrCP})$-dependent manner $[66,67]$. Cells expressing $\mathrm{Vpu}$ redistribute $\beta \mathrm{TrCP}$ from the nucleus to the cytoplasm [61]. The signal for the recognition of $\mathrm{Vpu}$ by $\beta$ TrCP is the phosphorylation of one or two serine residues present in a conserved motif, DSGXXS. Other elements in the cytoplasm regulate Vpu-induced downregulation of BST2. A putative trafficking motif, EXXXLV, in the second $\alpha$-helix of the cytoplasmic domain of Vpu directs Vpu-bound membrane protein into the endosomal degradation pathway. In the absence of this motif, Vpu/BST2 complexes are incorporated into nascent virions, and virus release from CD4+ $\mathrm{T}$ cells becomes impaired [68]. The proposed general model to explain the Vpu-induced degradation of membrane proteins requires the interaction of $\mathrm{Vpu}$ and the targeted protein via their transmembrane domains. Subsequently, the recruitment of the cofactor $\beta \mathrm{TrCP}$ allows the formation of a ternary complex that targets substrates, such as CD4 or BST2, to degradation via the ubiquitin proteasome pathway [28,69]. Alternatively, in the case of BST2, another model has been proposed whereby Vpu induces the endosome-lysosome pathway and endosomal sorting complexes required for transport (ESCRT)-mediated degradation of BST2 [70-72]. Interestingly, recent NMR studies have shown that the cytoplasmic domain of Vpu interacts with lipids at the plasma membrane via the W76 residue, and this interaction specifically displaces BST2 from viral assembly sites [32]. Thus, as discussed below, Vpu variants may show impaired ability for BST2 degradation while preserving the enhancement of virus release [73].

\section{Vpu Adjusts the Protein Composition and Functioning of Cellular Membranes}

In addition to the degradation of membrane proteins discussed above, Vpu induces the diversion of membrane proteins from their intrinsic trafficking pathways to alternative compartments away from degradation. This is the case for Env and Group-specific antigen (Gag) viral proteins which, in the absence of $\mathrm{Vpu}$, accumulate in endosomes, but in the presence of $\mathrm{Vpu}$, traffic to the plasma membrane for virus assembly and budding $[63,64,74]$. The role of $\mathrm{Vpu}$ in the subcellular transport of both virion components is cell-type dependent and occurs even when virion assembly takes place in late endosomes and virus release through the exosomal pathway [75-77]. Early studies suggested that the ion channel activity of Vpu may affect the trafficking of membrane proteins across internal cellular membranes [21]. Dissipation of ionic gradients within the endosomal system by Vpu may promote the recruitment of the ESCRT machinery required for budding [63,78]. This model was corroborated by the observation that membrane depolarization correlates with Vpu-mediated virus egress by budding [39]. The role of Vpu viroporin in the modulation of virus dissemination through direct cell-to-cell contacts at the virological synapse remains to be clarified $[79,80]$.

The difficulty to elucidate the structure and conformation of membrane proteins in their native membrane environment limits the characterization of Vpu-formed channel/pore structures [81,82]. NMR and molecular dynamics simulation studies proposed that oligomerized Vpu forms ion channels with weak cation selectivity $[35,83,84]$. Additionally, functional approaches using artificial membranes or cellular models revealed that full-length $\mathrm{Vpu}$ protein permeabilizes membranes to cations, amino acids and also charged molecules such as hygromycin B and neurobiotin [21,36,85]. Thus, there is an ongoing debate about whether Vpu should be considered as a strict ion channel or rather as a pore [86,87]. 


\section{Conservation and Heterogeneity of the Vpu Protein among Human and Non-Human Primate Isolates}

Primate lentiviruses have acquired "accessory" genes that allow continuous and efficient viral replication despite apparently strong innate and acquired immune responses [88]. The genome of the human lentivirus HIV-1 and also some of the simian lentivirus, such as simian immunodeficiency virus (SIV)cpz, SIVgsn, SIVmon, SIVden, SIVmus and SIVgor, include the accessory gene vpu [89]. The genome of human HIV-2 lacks the $v p u$ gene, but encodes an envelope glycoprotein that displays Vpu-like activity [90].

\subsection{Conservation of Vpu Functions in Natural Isolates}

The recent availability of Vpu sequences has provided new insights into lentivirus evolution and the contribution of $\mathrm{Vpu}$ to viral pathogenesis. Comparative studies of natural isolates showed that $\mathrm{Vpu}$ is one of the most highly variable proteins in the HIV-1 proteome [91]. The three HIV-1 phylogenetic groups, $\mathrm{M}$ (main), $\mathrm{O}$ (outlier), and $\mathrm{N}$ (non-M, non-O), can be discriminated by the ability of their corresponding Vpu proteins to downregulate CD4 and BST2 proteins [92] (Table 2). Vpu protein from the rare $\mathrm{N}$ strains lacks anti-CD4 activity, whereas Vpu proteins from the non-pandemic O group are poor BST2 antagonists [93]. Additionally, Vpu proteins from the global pandemic M strains are fully functional for antagonistic CD4 and BST2 activities. Moreover, Vpu protein from the low spread O group is retained in the ER rather than in the TGN, as occurs in the M group. In agreement with these observations, group O isolates use the Nef protein to antagonize BST2 [94]. Conceivably, viruses have evolved to counteract this antiviral factor [95].

Table 2. Host-adaptation activities of Vpus from each HIV-1 group. The putative P group is extremely rare and is thought to originate from a virus transmission from gorillas [96]. Viruses from M, N and O groups originate from SIV strains found in chimpanzees [97].

\begin{tabular}{ccccc}
\hline Group & CD4 Downregulation & BST2 Downregulation & Localization of Vpu & References \\
\hline P? & no & no & $?$ & {$[98,99]$} \\
N & no & poor & TGN & {$[100]$} \\
O & yes & Nef-mediated & ER & {$[93,99]$} \\
M & yes & yes & TGN & {$[100]$} \\
\hline
\end{tabular}

Nevertheless, the trafficking motif, EXXXLV, is well conserved in Vpu from A, B, D, G, and $\mathrm{H}$ subtypes of the $\mathrm{M}$ group and also from the $\mathrm{O}$ group. It is not clear, however, whether this $\mathrm{Vpu}$ motif acts in the TGN or in the plasma membrane [68,101]. The above-mentioned W76 residue in the Vpu cytoplasmic domain is well conserved in Vpu proteins from B, D, G, and J subtypes of the M group; however, a W76G polymorphism could be detected during the course of infection and also in most F subtype isolates [32,102]. Vpu proteins with a W76G substitution were impaired in their ability to enhance virion release despite preserved activity in the downregulation of BST2 protein from the cell surface. 


\subsection{Sequence Requirement of Vpu Functions}

The majority of functional and computer simulation studies on Vpu have been performed with Vpu proteins from the M group, specifically from the subtype B such as HXB2/HXB3 isolates. Site-directed mutagenesis studies with $\mathrm{Vpu}_{\mathrm{NL} 4-3}$ from a laboratory-adapted virus showed that mutation S52N, S56N at the $\beta \mathrm{TrCP}$ binding site renders Vpu unable to downregulate BST2 but partially capable of enhancing virion release [29,70]. Other studies suggested that S23 was essential for Vpu ion channel activity, although most isolates from group M carry the S23T substitution [86,89]. The S23A mutation impairs Vpu ion channel activity in patch-clamp experiments in 293T cells but does not affect its interaction with BST2 [55,103]. Similarly, mutations at conserved A10, A14 or A18 residues of the Vpu transmembrane domain impaired particle release and downregulation of the BST2 surface expression activities, but not downregulation of the CD4 surface expression or ion channel activity [103]. Furthermore, recent data have shown that over the course of infection, the Vpu amino acid sequence can be highly variable within an individual [104]. Despite the high variation of Vpu protein within one infected individual, the downregulation of CD4 and BST2 and also the enhancement of virion release are strictly maintained throughout HIV-1 infection [104]. Evidently, these novel data confirm the relevance of Vpu not only for virus spread but also for its in vivo persistence in infected individuals. The conservation of other $\mathrm{Vpu}$ activities, such as channel/pore forming, awaits further investigation. Presumably, the comparison of sequences from transmitted/founder and chronic viruses will reveal new determinants for each $\mathrm{Vpu}$ function [102].

\section{Vpu Viroporin as a Therapeutic Target}

The contribution of Vpu to virus transmission and also its persistence along the disease progression highlight the considerable therapeutic potential of this viroporin [104]. To date, the majority of efforts to develop specific anti-Vpu drugs have concentrated on the ability of viroporins to disturb ionic currents in membranes. This strategy has led to the search for inhibitors of other viroporins [105]. The first approaches to search for Vpu inhibitors utilized the measurement of ionic currents in artificial planar lipid bilayers [106], a methodology that led to the discovery of 5-(N,N-Hexamethylene) amiloride (HMA) as the first Vpu inhibitor [107]. Further evaluation of HMA in cellular models, unfortunately, demonstrated HMA to have low effectiveness due to its low selectivity index. Additional studies with amiloride analogues resulted in the discovery of a second inhibitor of Vpu ion channel activity, BIT225 [108]. The synthesized drug also inhibits the ion channel activity of the hepatitis $\mathrm{C}$ virus (HCV) viroporin, p7 [109]. This new compound demonstrated a superior selectivity index and has entered into phase two clinical trials. Recent data released from the BIT225 licensing company suggest its efficacy in HIV/HCV coinfected patients when used in combination with HCV drugs.

Evidence for functional complementation between $\mathrm{Vpu}$ and other viroporins have provided an alternative infection context to assess Vpu activity [65,110]. Thus, a single amino acid substitution in the Vpu transmembrane domain of a chimeric SIV/HIV virus (A19H) resulted in virus sensitization to rimantadine [111]. Consequently, the transmembrane domain of $\mathrm{Vpu}$ was proposed as an antiviral target. Further NMR structural analysis showed how this local change in the primary sequence affects secondary and tertiary structures of Vpu transmembrane peptide in lipid bilayers and alters drug binding 
to the viroporin [112]. Other recent studies have proposed alternative cellular models that are suitable for screening of inhibitors of full-length Vpu. Notably, the K+ dependent growth stimulation caused by Vpu protein in S. cerevisiae and also in Escherichia coli provides efficient cellular platforms to develop high-throughput screening assays [41,113]. Finally, Xenopus oocytes have also been used for drug testing for anti-Vpu activity by voltage clamp assays [114]. Clearly, inhibitors preselected with these phenotypic assays should be further validated in viral infections with representative pandemic strains.

\section{Conclusions and Perspectives}

$\mathrm{Vpu}$ viroporin is prominently involved in the spread of HIV-1 from infected cells. The precise mechanisms underlying this activity remain to be characterized. Nonetheless, the increase in number of available laboratory models to analyze Vpu separated from other cytotoxic viral proteins and the scope of sequences from natural isolates are providing new insights into the Vpu mode of action. Cell-type dependency for most of the Vpu functions may explain its apparent redundant and even opposite modes of functioning. Several lines of evidence indicate that Vpu antagonizes host restriction factors that interfere with virus dissemination. Vpu also modifies the composition and functioning of cellular membranes, which become adjusted to viral requirements at late stages of the virus life cycle. The overall architecture of $\mathrm{Vpu}$ seems to be essential for its functionality, more so than the specific amino acid sequence. Indeed, the variable supramolecular organization in subcellular compartments and also the turnover of the viroporin may modulate the contribution of Vpu's pleiotropic functions to the enhancement of virus spread. Further studies should clarify the differential mode of action of $\mathrm{Vpu}$ in cell-free and cell-cell virus transmissions and in plasma membrane or multivesicular virion assemblies. So far, there is no specific anti-Vpu drug that has passed clinical trials further than phase two. Nevertheless, available cell-based phenotypic screening assays are ready to search for anti-Vpu drugs.

\section{Acknowledgments}

This work was supported by grant PI08/0912 from FIS. The English language correction of the manuscript by Kenneth McCreath is acknowledged.

\section{Conflicts of Interest}

The author declares no conflict of interest.

\section{References}

1. Cohen, A.; Terwilliger, E.F.; Sodroski, J.G.; Haseltine, W.A. Identification of a protein encoded by the $v p u$ gene of HIV-1. Nature 1988, 334, 532-534. [CrossRef] [PubMed]

2. Strebel, K.; Klimkait, T.; Martin, M.A. A novel gene of HIV-1, vpu, and its 16-kilodalton product. Science 1988, 241, 1221-1223. [CrossRef] [PubMed]

3. Carrasco, L. Modification of membrane permeability by animal viruses. Adv. Virus Res. 1995, 45, 61-112. [PubMed]

4. Gonzalez, M.E.; Carrasco, L. Viroporins. FEBS Lett. 2003, 552, 28-34. [CrossRef]

5. Nieva, J.L.; Madan, V.; Carrasco, L. Viroporins: Structure and biological functions. Nat. Rev. Microbiol. 2012, 10, 563-574. [CrossRef] [PubMed] 
6. Schwartz, S.; Felber, B.K.; Fenyo, E.M.; Pavlakis, G.N. Env and Vpu proteins of human immunodeficiency virus type 1 are produced from multiple bicistronic mRNAs. J. Virol. 1990, 64, 5448-5456. [PubMed]

7. Willey, R.L.; Maldarelli, F.; Martin, M.A.; Strebel, K. Human immunodeficiency virus type 1 Vpu protein induces rapid degradation of CD4. J. Virol. 1992, 66, 7193-7200. [PubMed]

8. Strebel, K.; Klimkait, T.; Maldarelli, F.; Martin, M.A. Molecular and biochemical analyses of human immunodeficiency virus type $1 \mathrm{Vpu}$ protein. J. Virol. 1989, 63, 3784-3791. [PubMed]

9. Marassi, F.M.; Ma, C.; Gratkowski, H.; Straus, S.K.; Strebel, K.; Oblatt-Montal, M.; Montal, M.; Opella, S.J. Correlation of the structural and functional domains in the membrane protein Vpu from HIV-1. Proc. Natl. Acad. Sci. USA 1999, 96, 14336-14341. [CrossRef] [PubMed]

10. Schubert, U.; Bour, S.; Ferrer-Montiel, A.V.; Montal, M.; Maldarelli, F.; Strebel, K. The two biological activities of human immunodeficiency virus type $1 \mathrm{Vpu}$ protein involve two separable structural domains. J. Virol. 1996, 70, 809-819. [PubMed]

11. Willey, R.L.; Maldarelli, F.; Martin, M.A.; Strebel, K. Human immunodeficiency virus type 1 Vpu protein regulates the formation of intracellular gp160-CD4 complexes. J. Virol. 1992, 66, 226-234. [PubMed]

12. Geraghty, R.J.; Panganiban, A.T. Human immunodeficiency virus type 1 Vpu has a CD4- and an envelope glycoprotein-independent function. J. Virol. 1993, 67, 4190-4194. [PubMed]

13. Wray, V.; Federau, T.; Henklein, P.; Klabunde, S.; Kunert, O.; Schomburg, D.; Schubert, U. Solution structure of the hydrophilic region of HIV-1 encoded virus protein $\mathrm{U}(\mathrm{Vpu})$ by $\mathrm{CD}$ and 1H NMR spectroscopy. Int. J. Pept. Protein Res. 1995, 45, 35-43. [CrossRef] [PubMed]

14. Chen, M.Y.; Maldarelli, F.; Karczewski, M.K.; Willey, R.L.; Strebel, K. Human immunodeficiency virus type $1 \mathrm{Vpu}$ protein induces degradation of CD4 in vitro: The cytoplasmic domain of CD4 contributes to Vpu sensitivity. J. Virol. 1993, 67, 3877-3884. [PubMed]

15. Schubert, U.; Strebel, K. Differential activities of the human immunodeficiency virus type 1-encoded $\mathrm{Vpu}$ protein are regulated by phosphorylation and occur in different cellular compartments. J. Virol. 1994, 68, 2260-2271. [PubMed]

16. Veillette, M.; Desormeaux, A.; Medjahed, H.; Gharsallah, N.E.; Coutu, M.; Baalwa, J.; Guan, Y.; Lewis, G.; Ferrari, G.; Hahn, B.H.; et al. Interaction with cellular CD4 exposes HIV-1 envelope epitopes targeted by antibody-dependent cell-mediated cytotoxicity. J. Virol. 2014, 88, 2633-2644. [CrossRef] [PubMed]

17. Pham, T.N.; Lukhele, S.; Hajjar, F.; Routy, J.P.; Cohen, E.A. HIV Nef and Vpu protect HIV-infected CD4+ T cells from antibody-mediated cell lysis through down-modulation of CD4 and BST2. Retrovirology 2014, 11, e15. [CrossRef] [PubMed]

18. Balliet, J.W.; Kolson, D.L.; Eiger, G.; Kim, F.M.; McGann, K.A.; Srinivasan, A.; Collman, R. Distinct effects in primary macrophages and lymphocytes of the human immunodeficiency virus type 1 accessory genes $v p r, v p u$, and nef: Mutational analysis of a primary HIV-1 isolate. Virology 1994, 200, 623-631. [CrossRef] [PubMed]

19. Geraghty, R.J.; Talbot, K.J.; Callahan, M.; Harper, W.; Panganiban, A.T. Cell type-dependence for Vpu function. J. Med. Primatol. 1994, 23, 146-150. [CrossRef] [PubMed] 
20. Sakai, H.; Tokunaga, K.; Kawamura, M.; Adachi, A. Function of human immunodeficiency virus type 1 Vpu protein in various cell types. J. Gen. Virol. 1995, 76, 2717-2722. [CrossRef] [PubMed]

21. Ewart, G.D.; Sutherland, T.; Gage, P.W.; Cox, G.B. The Vpu protein of human immunodeficiency virus type 1 forms cation-selective ion channels. J. Virol. 1996, 70, 7108-7115. [PubMed]

22. Deora, A.; Ratner, L. Viral protein U (Vpu)-mediated enhancement of human immunodeficiency virus type 1 particle release depends on the rate of cellular proliferation. J. Virol. 2001, 75, 6714-6718. [CrossRef] [PubMed]

23. Neil, S.J.; Sandrin, V.; Sundquist, W.I.; Bieniasz, P.D. An interferon-alpha-induced tethering mechanism inhibits HIV-1 and Ebola virus particle release but is counteracted by the HIV-1 Vpu protein. Cell Host Microbe 2007, 2, 193-203. [CrossRef] [PubMed]

24. Neil, S.J.; Zang, T.; Bieniasz, P.D. Tetherin inhibits retrovirus release and is antagonized by HIV-1 Vpu. Nature 2008, 451, 425-430. [CrossRef] [PubMed]

25. Kupzig, S.; Korolchuk, V.; Rollason, R.; Sugden, A.; Wilde, A.; Banting, G. Bst-2/HM1.24 is a raft-associated apical membrane protein with an unusual topology. Traffic 2003, 4, 694-709. [CrossRef] [PubMed]

26. Perez-Caballero, D.; Zang, T.; Ebrahimi, A.; McNatt, M.W.; Gregory, D.A.; Johnson, M.C.; Bieniasz, P.D. Tetherin inhibits HIV-1 release by directly tethering virions to cells. Cell 2009, 139, 499-511. [CrossRef] [PubMed]

27. Van, D.N.; Goff, D.; Katsura, C.; Jorgenson, R.L.; Mitchell, R.; Johnson, M.C.; Stephens, E.B.; Guatelli, J. The interferon-induced protein BST-2 restricts HIV-1 release and is downregulated from the cell surface by the viral Vpu protein. Cell Host Microbe 2008, 3, 245-252.

28. Goffinet, C.; Allespach, I.; Homann, S.; Tervo, H.M.; Habermann, A.; Rupp, D.; Oberbremer, L.; Kern, C.; Tibroni, N.; Welsch, S.; et al. HIV-1 antagonism of CD317 is species specific and involves Vpu-mediated proteasomal degradation of the restriction factor. Cell Host Microbe 2009, 5, 285-297. [CrossRef] [PubMed]

29. Iwabu, Y.; Fujita, H.; Kinomoto, M.; Kaneko, K.; Ishizaka, Y.; Tanaka, Y.; Sata, T.; Tokunaga, K. HIV-1 accessory protein Vpu internalizes cell-surface BST-2/tetherin through transmembrane interactions leading to lysosomes. J. Biol. Chem. 2009, 284, 35060-35072. [CrossRef] [PubMed]

30. McNatt, M.W.; Zang, T.; Hatziioannou, T.; Bartlett, M.; Fofana, I.B.; Johnson, W.E.; Neil, S.J.; Bieniasz, P.D. Species-specific activity of HIV-1 Vpu and positive selection of tetherin transmembrane domain variants. PLoS Pathog. 2009, 5, e1000300. [CrossRef] [PubMed]

31. Dube, M.; Roy, B.B.; Guiot-Guillain, P.; Mercier, J.; Binette, J.; Leung, G.; Cohen, E.A. Suppression of Tetherin-restricting activity upon human immunodeficiency virus type 1 particle release correlates with localization of $\mathrm{Vpu}$ in the trans-Golgi network. J. Virol. 2009, 83, 4574-4590. [CrossRef] [PubMed]

32. Lewinski, M.K.; Jafari, M.; Zhang, H.; Opella, S.J.; Guatelli, J. Membrane Anchoring by a C-terminal Tryptophan Enables HIV-1 Vpu to Displace Bone Marrow Stromal Antigen 2 (BST2) from Sites of Viral Assembly. J. Biol. Chem. 2015, 290, 10919-10933. [CrossRef] [PubMed]

33. Maldarelli, F.; Chen, M.Y.; Willey, R.L.; Strebel, K. Human immunodeficiency virus type 1 $\mathrm{Vpu}$ protein is an oligomeric type I integral membrane protein. J. Virol. 1993, 67, 5056-5061. [PubMed] 
34. Pinto, L.H.; Holsinger, L.J.; Lamb, R.A. Influenza virus M2 protein has ion channel activity. Cell 1992, 69, 517-528. [CrossRef]

35. Grice, A.L.; Kerr, I.D.; Sansom, M.S. Ion channels formed by HIV-1 Vpu: A modelling and simulation study. FEBS Lett. 1997, 405, 299-304. [CrossRef]

36. Schubert, U.; Ferrer-Montiel, A.V.; Oblatt-Montal, M.; Henklein, P.; Strebel, K.; Montal, M. Identification of an ion channel activity of the Vpu transmembrane domain and its involvement in the regulation of virus release from HIV-1-infected cells. FEBS Lett. 1996, 398, 12-18. [CrossRef]

37. Coady, M.J.; Daniel, N.G.; Tiganos, E.; Allain, B.; Friborg, J.; Lapointe, J.Y.; Cohen, E.A. Effects of Vpu expression on Xenopus oocyte membrane conductance. Virology 1998, 244, 39-49. [CrossRef] [PubMed]

38. Ma, C.; Marassi, F.M.; Jones, D.H.; Straus, S.K.; Bour, S.; Strebel, K.; Schubert, U.; Oblatt-Montal, M.; Montal, M.; Opella, S.J. Expression, purification, and activities of full-length and truncated versions of the integral membrane protein Vpu from HIV-1. Protein Sci. 2002, 11, 546-557. [CrossRef] [PubMed]

39. Hsu, K.; Han, J.; Shinlapawittayatorn, K.; Deschenes, I.; Marban, E. Membrane potential depolarization as a triggering mechanism for Vpu-mediated HIV-1 release. Biophys. J. 2010, 99, 1718-1725. [CrossRef] [PubMed]

40. Hsu, K.; Seharaseyon, J.; Dong, P.; Bour, S.; Marban, E. Mutual functional destruction of HIV-1 Vpu and host TASK-1 channel. Mol. Cell 2004, 14, 259-267. [CrossRef]

41. Herrero, L.; Monroy, N.; Gonzalez, M.E. HIV-1 Vpu protein mediates the transport of potassium in Saccharomyces cerevisiae. Biochemistry 2013, 52, 171-177. [CrossRef] [PubMed]

42. Sato, H.; Orenstein, J.; Dimitrov, D.; Martin, M. Cell-to-cell spread of HIV-1 occurs within minutes and may not involve the participation of virus particles. Virology 1992, 186, 712-724. [CrossRef]

43. Klimkait, T.; Strebel, K.; Hoggan, M.D.; Martin, M.A.; Orenstein, J.M. The human immunodeficiency virus type 1-specific protein $\mathrm{Vpu}$ is required for efficient virus maturation and release. J. Virol. 1990, 64, 621-629. [PubMed]

44. Lu, J.X.; Sharpe, S.; Ghirlando, R.; Yau, W.M.; Tycko, R. Oligomerization state and supramolecular structure of the HIV-1 Vpu protein transmembrane segment in phospholipid bilayers. Protein Sci. 2010, 19, 1877-1896. [CrossRef] [PubMed]

45. Estrabaud, E.; Le, R.E.; Lopez-Verges, S.; Morel, M.; Belaidouni, N.; Benarous, R.; Transy, C.; Berlioz-Torrent, C.; Margottin-Goguet, F. Regulated degradation of the HIV-1 Vpu protein through a betaTrCP-independent pathway limits the release of viral particles. PLoS Pathog. 2007, 3, e104. [CrossRef] [PubMed]

46. Hussain, A.; Das, S.R.; Tanwar, C.; Jameel, S. Oligomerization of the human immunodeficiency virus type 1 (HIV-1) Vpu protein-A genetic, biochemical and biophysical analysis. Virol. J. 2007, 4, e81. [CrossRef] [PubMed]

47. Waheed, A.A.; Freed, E.O. The Role of Lipids in Retrovirus Replication. Viruses 2010, 2 , 1146-1180. [CrossRef] [PubMed]

48. Tokarev, A.; Guatelli, J. Misdirection of membrane trafficking by HIV-1 Vpu and Nef: Keys to viral virulence and persistence. Cell. Logist. 2011, 1, 90-102. [CrossRef] [PubMed] 
49. Ramirez, P.W.; Famiglietti, M.; Sowrirajan, B.; DePaula-Silva, A.B.; Rodesch, C.; Barker, E.; Bosque, A.; Planelles, V. Downmodulation of CCR7 by HIV-1 Vpu results in impaired migration and chemotactic signaling within CD4(+) T cells. Cell Rep. 2014, 7, 2019-2030. [CrossRef] [PubMed]

50. Moll, M.; Andersson, S.K.; Smed-Sorensen, A.; Sandberg, J.K. Inhibition of lipid antigen presentation in dendritic cells by HIV-1 Vpu interference with CD1d recycling from endosomal compartments. Blood 2010, 116, 1876-1884. [CrossRef] [PubMed]

51. Bachle, S.M.; Sauter, D.; Sibitz, S.; Sandberg, J.K.; Kirchhoff, F.; Moll, M. Involvement of a C-terminal motif in the interference of primate lentiviral Vpu proteins with CD1d-mediated antigen presentation. Sci. Rep. 2015, 5, 9675. [CrossRef] [PubMed]

52. Henderson, W.W.; Ruhl, R.; Lewis, P.; Bentley, M.; Nelson, J.A.; Moses, A.V. Human immunodeficiency virus (HIV) type $1 \mathrm{Vpu}$ induces the expression of CD40 in endothelial cells and regulates HIV-induced adhesion of B-lymphoma cells. J. Virol. 2004, 78, 4408-4420. [CrossRef] [PubMed]

53. Lambele, M.; Koppensteiner, H.; Symeonides, M.; Roy, N.H.; Chan, J.; Schindler, M.; Thali, M. $\mathrm{Vpu}$ is the main determinant for tetraspanin downregulation in HIV-1-infected cells. J. Virol. 2015, 89, 3247-3255. [CrossRef] [PubMed]

54. Matusali, G.; Potesta, M.; Santoni, A.; Cerboni, C.; Doria, M. The human immunodeficiency virus type $1 \mathrm{Nef}$ and Vpu proteins downregulate the natural killer cell-activating ligand PVR. J. Virol. 2012, 86, 4496-4504. [CrossRef] [PubMed]

55. Bolduan, S.; Reif, T.; Schindler, M.; Schubert, U. HIV-1 Vpu mediated downregulation of CD155 requires alanine residues 10, 14 and 18 of the transmembrane domain. Virology 2014, 464-465, 375-384. [CrossRef] [PubMed]

56. Vassena, L.; Giuliani, E.; Koppensteiner, H.; Bolduan, S.; Schindler, M.; Doria, M. HIV-1 Nef and Vpu Interfere with L-Selectin (CD62L) Cell Surface Expression To Inhibit Adhesion and Signaling in Infected CD4+ T Lymphocytes. J. Virol. 2015, 89, 5687-5700. [CrossRef] [PubMed]

57. Kerkau, T.; Bacik, I.; Bennink, J.R.; Yewdell, J.W.; Hunig, T.; Schimpl, A.; Schubert, U. The human immunodeficiency virus type $1(\mathrm{HIV}-1) \mathrm{Vpu}$ protein interferes with an early step in the biosynthesis of major histocompatibility complex (MHC) class I molecules. J. Exp. Med. 1997, 185, 1295-1305. [CrossRef] [PubMed]

58. Shah, A.H.; Sowrirajan, B.; Davis, Z.B.; Ward, J.P.; Campbell, E.M.; Planelles, V.; Barker, E. Degranulation of natural killer cells following interaction with HIV-1-infected cells is hindered by downmodulation of NTB-A by Vpu. Cell Host Microbe 2010, 8, 397-409. [CrossRef] [PubMed]

59. Richard, J.; Cohen, E.A. HIV-1 Vpu disarms natural killer cells. Cell Host Microbe 2010, 8, 389-391. [CrossRef] [PubMed]

60. Jia, X.; Weber, E.; Tokarev, A.; Lewinski, M.; Rizk, M.; Suarez, M.; Guatelli, J.; Xiong, Y. Structural basis of HIV-1 Vpu-mediated BST2 antagonism via hijacking of the clathrin adaptor protein complex 1. Elife 2014, 3, e02362. [CrossRef] [PubMed]

61. Besnard-Guerin, C.; Belaidouni, N.; Lassot, I.; Segeral, E.; Jobart, A.; Marchal, C.; Benarous, R. HIV-1 Vpu sequesters beta-transducin repeat-containing protein (betaTrCP) in the cytoplasm and 
provokes the accumulation of beta-catenin and other SCFbetaTrCP substrates. J. Biol. Chem. 2004, 279, 788-795. [CrossRef] [PubMed]

62. Haller, C.; Muller, B.; Fritz, J.V.; Lamas-Murua, M.; Stolp, B.; Pujol, F.M.; Keppler, O.T.; Fackler, O.T. HIV-1 Nef and Vpu are functionally redundant broad-spectrum modulators of cell surface receptors, including tetraspanins. J. Virol. 2014, 88, 14241-14257. [CrossRef] [PubMed]

63. Van, D.N.; Guatelli, J. HIV-1 Vpu inhibits accumulation of the envelope glycoprotein within clathrin-coated, Gag-containing endosomes. Cell Microbiol. 2008, 10, 1040-1057.

64. Handley, M.A.; Paddock, S.; Dall, A.; Panganiban, A.T. Association of Vpu-binding protein with microtubules and Vpu-dependent redistribution of HIV-1 Gag protein. Virology 2001, 291, 198-207. [CrossRef] [PubMed]

65. Gonzalez, M.E.; Carrasco, L. Human immunodeficiency virus type 1 Vpu protein affects Sindbis virus glycoprotein processing and enhances membrane permeabilization. Virology 2001, 279, 201-209. [CrossRef] [PubMed]

66. Magadan, J.G.; Perez-Victoria, F.J.; Sougrat, R.; Ye, Y.; Strebel, K.; Bonifacino, J.S. Multilayered mechanism of CD4 downregulation by HIV-1 Vpu involving distinct ER retention and ERAD targeting steps. PLoS Pathog. 2010, 6, e1000869. [CrossRef] [PubMed]

67. Mangeat, B.; Gers-Huber, G.; Lehmann, M.; Zufferey, M.; Luban, J.; Piguet, V. HIV-1 Vpu neutralizes the antiviral factor Tetherin/BST-2 by binding it and directing its beta-TrCP2-dependent degradation. PLoS Pathog. 2009, 5, e1000574. [CrossRef] [PubMed]

68. Kueck, T.; Neil, S.J. A cytoplasmic tail determinant in HIV-1 Vpu mediates targeting of tetherin for endosomal degradation and counteracts interferon-induced restriction. PLoS Pathog. 2012, 8, e1002609. [CrossRef] [PubMed]

69. Margottin, F.; Bour, S.P.; Durand, H.; Selig, L.; Benichou, S.; Richard, V.; Thomas, D.; Strebel, K.; Benarous, R. A novel human WD protein, h-beta TrCp, that interacts with HIV-1 Vpu connects CD4 to the ER degradation pathway through an F-box motif. Mol. Cell 1998, 1, 565-574. [CrossRef]

70. Douglas, J.L.; Viswanathan, K.; McCarroll, M.N.; Gustin, J.K.; Fruh, K.; Moses, A.V. Vpu directs the degradation of the human immunodeficiency virus restriction factor BST-2/Tetherin via a \{beta\}TrCP-dependent mechanism. J. Virol. 2009, 83, 7931-7947. [CrossRef] [PubMed]

71. Janvier, K.; Pelchen-Matthews, A.; Renaud, J.B.; Caillet, M.; Marsh, M.; Berlioz-Torrent, C. The ESCRT-0 component HRS is required for HIV-1 Vpu-mediated BST-2/tetherin down-regulation. PLoS Pathog. 2011, 7, e1001265. [CrossRef] [PubMed]

72. Petris, G.; Casini, A.; Sasset, L.; Cesaratto, F.; Bestagno, M.; Cereseto, A.; Burrone, O.R. CD4 and BST-2/tetherin proteins retro-translocate from endoplasmic reticulum to cytosol as partially folded and multimeric molecules. J. Biol. Chem. 2014, 289, 1-12. [CrossRef] [PubMed]

73. Miyagi, E.; Andrew, A.J.; Kao, S.; Strebel, K. Vpu enhances HIV-1 virus release in the absence of Bst-2 cell surface down-modulation and intracellular depletion. Proc. Natl. Acad. Sci. USA 2009, 106, 2868-2873. [CrossRef] [PubMed]

74. Neil, S.J.; Eastman, S.W.; Jouvenet, N.; Bieniasz, P.D. HIV-1 Vpu promotes release and prevents endocytosis of nascent retrovirus particles from the plasma membrane. PLoS Pathog. 2006, 2, e39. [CrossRef] [PubMed] 
75. Gautam, A.; Bhattacharya, J. Evidence that Vpu modulates HIV-1 Gag-envelope interaction towards envelope incorporation and infectivity in a cell type dependent manner. PLOS ONE 2013, 8, e61388. [CrossRef] [PubMed]

76. Balasubramaniam, M.; Freed, E.O. New insights into HIV assembly and trafficking. Physiology 2011, 26, 236-251. [CrossRef] [PubMed]

77. Joshi, A.; Ablan, S.D.; Soheilian, F.; Nagashima, K.; Freed, E.O. Evidence that productive human immunodeficiency virus type 1 assembly can occur in an intracellular compartment. J. Virol. 2009, 83, 5375-5387. [CrossRef] [PubMed]

78. Votteler, J.; Sundquist, W.I. Virus budding and the ESCRT pathway. Cell Host Microbe 2013, 14, 232-241. [CrossRef] [PubMed]

79. Casartelli, N.; Sourisseau, M.; Feldmann, J.; Guivel-Benhassine, F.; Mallet, A.; Marcelin, A.G.; Guatelli, J.; Schwartz, O. Tetherin restricts productive HIV-1 cell-to-cell transmission. PLoS Pathog. 2010, 6, e1000955. [CrossRef] [PubMed]

80. Jolly, C.; Booth, N.J.; Neil, S.J. Cell-cell spread of human immunodeficiency virus type 1 overcomes tetherin/BST-2-mediated restriction in T cells. J. Virol. 2010, 84, 12185-12199. [CrossRef] [PubMed]

81. Fischer, W.B.; Hsu, H.J. Viral channel forming proteins - modeling the target. Biochim. Biophys. Acta 2011, 1808, 561-571. [CrossRef] [PubMed]

82. Lamb, R.A.; Pinto, L.H. Do Vpu and Vpr of human immunodeficiency virus type 1 and NB of influenza B virus have ion channel activities in the viral life cycles? Virology 1997, 229, 1-11. [CrossRef] [PubMed]

83. Kukol, A.; Arkin, I.T. Vpu transmembrane peptide structure obtained by site-specific fourier transform infrared dichroism and global molecular dynamics searching. Biophys. J. 1999, 77, 1594-1601. [CrossRef]

84. Moore, P.B.; Zhong, Q.; Husslein, T.; Klein, M.L. Simulation of the HIV-1 Vpu transmembrane domain as a pentameric bundle. FEBS Lett. 1998, 431, 143-148. [CrossRef]

85. Gonzalez, M.E.; Carrasco, L. The human immunodeficiency virus type 1 Vpu protein enhances membrane permeability. Biochemistry 1998, 37, 13710-13719. [CrossRef] [PubMed]

86. Mehnert, T.; Routh, A.; Judge, P.J.; Lam, Y.H.; Fischer, D.; Watts, A.; Fischer, W.B. Biophysical characterization of $\mathrm{Vpu}$ from HIV-1 suggests a channel-pore dualism. Proteins 2008, 70, 1488-1497. [CrossRef] [PubMed]

87. Nieva, J.L.; Madan, V.; Carrasco, L. Viroporins: Structure and biological functions. Nat. Rev. Microbiol. 2012, 10, 563-574. [CrossRef] [PubMed]

88. Kirchhoff, F. Immune evasion and counteraction of restriction factors by HIV-1 and other primate lentiviruses. Cell Host Microbe 2010, 8, 55-67. [CrossRef] [PubMed]

89. Los Alamos HIV Sequence Database and Analysis Staff. HIV Sequence Compendium 2014; Theoretical Biology and Biophysics Group, Los Alamos National Laboratory: Los Alamos, NM, USA, 2014. Available online: http://www.hiv.lanl.gov/content/sequence/HIV/COMPENDIUM/ 2014compendium.html (accessed on 30 July 2015). 
90. Bour, S.; Strebel, K. The human immunodeficiency virus (HIV) type 2 envelope protein is a functional complement to HIV type $1 \mathrm{Vpu}$ that enhances particle release of heterologous retroviruses. J. Virol. 1996, 70, 8285-8300. [PubMed]

91. Yusim, K.; Kesmir, C.; Gaschen, B.; Addo, M.M.; Altfeld, M.; Brunak, S.; Chigaev, A.; Detours, V.; Korber, B.T. Clustering patterns of cytotoxic T-lymphocyte epitopes in human immunodeficiency virus type 1 (HIV-1) proteins reveal imprints of immune evasion on HIV-1 global variation. J. Virol. 2002, 76, 8757-8768. [CrossRef] [PubMed]

92. Sauter, D.; Schindler, M.; Specht, A.; Landford, W.N.; Munch, J.; Kim, K.A.; Votteler, J.; Schubert, U.; Bibollet-Ruche, F.; Keele, B.F.; et al. Tetherin-driven adaptation of Vpu and Nef function and the evolution of pandemic and nonpandemic HIV-1 strains. Cell Host Microbe 2009, 6, 409-421. [CrossRef] [PubMed]

93. Vigan, R.; Neil, S.J. Separable determinants of subcellular localization and interaction account for the inability of group O HIV-1 Vpu to counteract tetherin. J. Virol. 2011, 85, 9737-9748. [CrossRef] [PubMed]

94. Kluge, S.F.; Mack, K.; Iyer, S.S.; Pujol, F.M.; Heigele, A.; Learn, G.H.; Usmani, S.M.; Sauter, D.; Joas, S.; Hotter, D.; et al. Nef proteins of epidemic HIV-1 group O strains antagonize human tetherin. Cell Host Microbe 2014, 16, 639-650. [CrossRef] [PubMed]

95. Sauter, D. Counteraction of the multifunctional restriction factor tetherin. Front. Microbiol. 2014, 5, e163. [CrossRef] [PubMed]

96. Plantier, J.C.; Leoz, M.; Dickerson, J.E.; De, O.F.; Cordonnier, F.; Lemee, V.; Damond, F.; Robertson, D.L.; Simon, F. A new human immunodeficiency virus derived from gorillas. Nat. Med. 2009, 15, 871-872. [CrossRef] [PubMed]

97. Sharp, P.M.; Hahn, B.H. Origins of HIV and the AIDS pandemic. Cold Spring Harb. Perspect. Med. 2011, 1, a006841. [CrossRef] [PubMed]

98. Sauter, D.; Hue, S.; Petit, S.J.; Plantier, J.C.; Towers, G.J.; Kirchhoff, F.; Gupta, R.K. HIV-1 Group P is unable to antagonize human tetherin by Vpu, Env or Nef. Retrovirology 2011, 8, e103. [CrossRef] [PubMed]

99. Yang, S.J.; Lopez, L.A.; Exline, C.M.; Haworth, K.G.; Cannon, P.M. Lack of adaptation to human tetherin in HIV-1 group O and P. Retrovirology 2011, 8, e78. [CrossRef] [PubMed]

100. Sauter, D.; Unterweger, D.; Vogl, M.; Usmani, S.M.; Heigele, A.; Kluge, S.F.; Hermkes, E.; Moll, M.; Barker, E.; Peeters, M.; et al. Human tetherin exerts strong selection pressure on the HIV-1 group N Vpu protein. PLoS Pathog. 2012, 8, e1003093. [CrossRef] [PubMed]

101. McNatt, M.W.; Zang, T.; Bieniasz, P.D. Vpu binds directly to tetherin and displaces it from nascent virions. PLoS Pathog. 2013, 9, e1003299. [CrossRef] [PubMed]

102. Jafari, M.; Guatelli, J.; Lewinski, M.K. Activities of transmitted/founder and chronic clade B HIV-1 Vpu and a C-terminal polymorphism specifically affecting virion release. J. Virol. 2014, 88, 5062-5078. [CrossRef] [PubMed]

103. Bolduan, S.; Votteler, J.; Lodermeyer, V.; Greiner, T.; Koppensteiner, H.; Schindler, M.; Thiel, G.; Schubert, U. Ion channel activity of HIV-1 Vpu is dispensable for counteraction of CD317. Virology 2011, 416, 75-85. [CrossRef] [PubMed] 
104. Pickering, S.; Hue, S.; Kim, E.Y.; Reddy, S.; Wolinsky, S.M.; Neil, S.J. Preservation of tetherin and CD4 counter-activities in circulating Vpu alleles despite extensive sequence variation within HIV-1 infected individuals. PLoS Pathog. 2014, 10, e1003895. [CrossRef] [PubMed]

105. Gonzalez, M.E.; Carrasco, L. Viral proteins that enhance membrane permeability. In Viral Membrane Proteins: Structure, Function and Drug Design; Fischer, W.B., Ed.; Kluwer Academic/Plenum Publishers: New York, NY, USA, 2005; pp. 79-90. Available online: http://rd.springer.com/chapter/10.1007/0-387-28146-0_6\#page-1 (accessed on 30 July 2015).

106. Ewart, G.D.; Mills, K.; Cox, G.B.; Gage, P.W. Amiloride derivatives block ion channel activity and enhancement of virus-like particle budding caused by HIV-1 protein Vpu. Eur. Biophys. J. 2002, 31, 26-35. [CrossRef] [PubMed]

107. Ewart, G.D.; Nasr, N.; Naif, H.; Cox, G.B.; Cunningham, A.L.; Gage, P.W. Potential new anti-human immunodeficiency virus type 1 compounds depress virus replication in cultured human macrophages. Antimicrob. Agents Chemother. 2004, 48, 2325-2330. [CrossRef]

108. Khoury, G.; Ewart, G.; Luscombe, C.; Miller, M.; Wilkinson, J. Antiviral efficacy of the novel compound BIT225 against HIV-1 release from human macrophages. Antimicrob. Agents Chemother. 2010, 54, 835-845. [CrossRef] [PubMed]

109. Luscombe, C.A.; Huang, Z.; Murray, M.G.; Miller, M.; Wilkinson, J.; Ewart, G.D. A novel Hepatitis $\mathrm{C}$ virus $\mathrm{p} 7$ ion channel inhibitor, BIT225, inhibits bovine viral diarrhea virus in vitro and shows synergism with recombinant interferon-alpha-2b and nucleoside analogues. Antivir. Res. 2010, 86, 144-153. [CrossRef] [PubMed]

110. Hout, D.R.; Gomez, M.L.; Pacyniak, E.; Gomez, L.M.; Fegley, B.; Mulcahy, E.R.; Hill, M.S.; Culley, N.; Pinson, D.M.; Nothnick, W.; et al. Substitution of the transmembrane domain of $\mathrm{Vpu}$ in simian-human immunodeficiency virus (SHIVKU1bMC33) with that of M2 of influenza A results in a virus that is sensitive to inhibitors of the M2 ion channel and is pathogenic for pig-tailed macaques. Virology 2006, 344, 541-559. [CrossRef] [PubMed]

111. Hout, D.R.; Gomez, L.M.; Pacyniak, E.; Miller, J.M.; Hill, M.S.; Stephens, E.B. A single amino acid substitution within the transmembrane domain of the human immunodeficiency virus type 1 Vpu protein renders simian-human immunodeficiency virus (SHIV(KU-1bMC33)) susceptible to rimantadine. Virology 2006, 348, 449-461. [CrossRef] [PubMed]

112. Park, S.H.; Opella, S.J. Conformational changes induced by a single amino acid substitution in the trans-membrane domain of Vpu: Implications for HIV-1 susceptibility to channel blocking drugs. Protein Sci. 2007, 16, 2205-2215. [CrossRef] [PubMed]

113. Taube, R.; Alhadeff, R.; Assa, D.; Krugliak, M.; Arkin, I.T. Bacteria-based analysis of HIV-1 Vpu channel activity. PLoS ONE 2014, 9, e105387. [CrossRef] [PubMed]

114. Sauter, D.; Schwarz, S.; Wang, K.; Zhang, R.; Sun, B.; Schwarz, W. Genistein as antiviral drug against HIV ion channel. Planta Med. 2014, 80, 682-687. [CrossRef] [PubMed]

(C) 2015 by the author; licensee MDPI, Basel, Switzerland. This article is an open access article distributed under the terms and conditions of the Creative Commons Attribution license (http://creativecommons.org/licenses/by/4.0/). 